\title{
Penicillin-G: Efficacy against Flavobacterium psychrophilum and evaluation of lethal dose limits for rainbow trout
}

\author{
Eric J. Wagner ${ }^{*}$, Randall W. Oplinger, Matthew Bartley \\ Fisheries Experiment Station, Utah Division of Wildlife Resources, Logan, USA; \\ "Corresponding Author: ericwagner@utah.gov
}

Received 8 March 2012; revised 11 April 2012; accepted 23 April 2012

\begin{abstract}
The effect of penicillin-G on Flavobacterium psychrophilum, the cause of bacterial coldwater disease, was evaluated in $15 \mathrm{~min}$ and overnight exposures. Separate tests evaluated the effect of increasing doses of penicillin-G to rainbow trout Oncorhynchus mykiss eggs, fingerlings, and adults. Rainbow trout eggs were exposed for $1 \mathrm{~h}$ to penicillin doses of $0,250,500,1000,10,000$, 50,000 , or $100,000 \mathrm{IU} / \mathrm{mL}$. Mean percent hatch ranged from $64.6 \%$ to $75.1 \%$, and did not significantly differ among the treatments. Fingerlings were injected intraperitoneally (i.p.) with $200 \mu \mathrm{L}$ of $0,1,10,100,1000,10,000,100,000$, or $500,000 \mathrm{IU} / \mathrm{mL}$. Probit analysis resulted in a $\mathrm{LD}_{10}$ (lethal dose for $10 \%$ of injected fish) of 52,868 $\mathrm{IU} / \mathrm{mL}$ (95\% confidence limits: $31,522-69,490$ $\mathrm{IU} / \mathrm{mL})$ and $a L_{50}$ of $131,466 \mathrm{IU} / \mathrm{mL}(113,095$ $157,878 \mathrm{IU} / \mathrm{mL}$ ). Brood stock were injected (i.p.) with $200 \mu \mathrm{L}$ of penicillin at concentrations of 0 (control), 10,000, 50,000, 100,000, 200,000, 400,000 , or $800,000 \mathrm{IU} / \mathrm{mL}$. Mortality ranged from $0 \%$ to $7 \%(50,000 \mathrm{IU} / \mathrm{mL}$ treatment) and did not significantly differ among treatments. In 28 h exposure tests, penicillin concentrations of $\geq$ $333 \mathrm{IU} / \mathrm{mL}$ were required to completely suppress growth of $F$. psychrophilum. In 15 min exposures, $\geq 10,000 \mathrm{IU} / \mathrm{mL}$ were needed to achieve the same result. Tests indicated that rainbow trout eggs can tolerate $1 \mathrm{~h}$ exposures to penicillin-G concentrations as high as $100,000 \mathrm{IU} / \mathrm{mL}$, and that brood fish can tolerate injections of at least $800,000 \mathrm{IU} / \mathrm{mL}$. Fingerling data however, suggested that injection of doses greater than $10,000 \mathrm{IU} / \mathrm{mL}$ can be toxic. The data suggests rainbow trout eggs or brood can tolerate high doses of penicillin-G that could be used for controlling the transfer of $F$. psychrophilum to hatcheries receiving eggs.
\end{abstract}

Keywords: Flavobacterium psychrophilum; Penicillin; Antibiotics; Toxicity; Drug Safety

\section{INTRODUCTION}

Flavobacterium psychrophilum (formerly Cytophaga psychrophila) is a Gram-negative bacterium that can cause high mortality in fish populations. The bacterium is the etiological agent of rainbow trout fry syndrome or bacterial cold-water disease and is characterized by clinical signs that include skin necrosis, ulcers, myositis, deformities, hemorrhaging, and exophthalmia [1]. In Utah, hatchery records and case histories of disease outbreaks summarized in 2009 (E. Wagner, unpublished data) indicated that 1.3 million fish died between 2002 and 2009 in the state hatchery system due to F. psychrophilum. In an effort to prevent transmission of the bacteria from the Utah Division of Wildlife's brood hatchery, where fish harbor the pathogen, to rearing hatcheries, egg disinfection strategies are being evaluated [2]. Povidone iodine $(100 \mathrm{mg} / \mathrm{L}$ active iodine for $10 \mathrm{~min})$ is currently used for disinfection, but has been ineffective at complete control [3-5]. Research has also indicated that the bacterium is sequestered within the egg, where external treatments cannot treat it $[4,6]$. Similar sequestration of Renibacterium salmoninarum, the cause of bacterial kidney disease, has been related to the failure of iodophor treatment [7].

Antibiotics may provide a means to reach internal bacteria and prevent transmission of disease to eggs and fry. Injection of brood stock with antibiotics prior to spawning is also possible. A number of different studies with $F$. psychrophilum have reported on the efficacy of various antibiotics including oxytetracycline, amoxicillin, erythromycin, ormetoprim-sulfadimethoxine, ampicillin, doxycycline, enrofloxacin, florfenicol, flumequine, gentamicin, oxolinic acid, sarafloxacin, and sulfamethoxazole-trimethoprim [8-13]. These studies were primarily standard laboratory tests to determine minimum inhibi- 
tory concentrations (MIC; [14]) for each antibiotic in Petri dishes and to document increasing resistance of the bacteria to the antibiotics. Bruun et al. [15] took the MIC testing one step further by evaluating the ability of a medicated feed (100 mg oxytetracycline $/ \mathrm{kg}$ fish) to treat fish exposed to $F$. psychrophilum strains with different levels of antibiotic resistance. Similarly, Soltani et al. [16] evaluated both MIC and in-vivo efficacy of oxolinic acid, amoxicillin, or trimethoprim again several Cytophaga and Flexibacter species. Bustos et al. [17] noted that despite high drug sensitivity in-vitro, field application indicated little to no effect with flumequine, oxolinic acid, or high doses of oxytetracycline.

Penicillin refers to a group of related natural and semi-synthetic antibiotics that are derived from the mold genus Penicillium and widely used in human and veterinary medicine. Penicillin-G is benzylpenicillin, usually prepared as a sodium or potassium salt [18]. The bactericidal effect of penicillin is caused by inhibition of bacterial cell wall synthesis [19]. Penicillin-G is useful for control of many Gram positive bacteria, streptococci, Bacillis anthracis, some Corynebacterium species, and many anaerobes $[20,21]$. However, penicillin is inactivated by bacteria that produce $\beta$-lactamases and is ineffective against bacteria with a relatively impermeable cell wall, such as staphylococci and many gram-negative bacteria [21]. However, Lumsden et al. [22] noted that $F$. psychrophilum was susceptible to penicillin in a disk test. At the Fisheries Experiment Station we have similarly observed sensitivity to disks of penicillin by isolates of $F$. psychrophilum, indicating the antibiotic may be useful for control of bacterial cold-water disease. In this study, the objective was to determine penicillin concentrations that controlled the growth of $F$. psychrophilum in short (15 min) and longer term (overnight) exposures. In addition, we wanted to evaluate the effect of higher concentrations of penicillin on rainbow trout Oncorhynchus mykiss and determine potential dose limits for use for different life stages.

\section{METHODS}

The potassium salt of Penicillin-G (Alpharma, Bridgewater, New Jersey, lot PRH90078, 1.582 million IU/g) was used for all the tests. Rainbow trout for the study were obtained as eggs from the J. Perry Egan State Fish Hatchery, Bicknell, Utah. Tests evaluating the potential lethal dose of penicillin-G were conducted on freshly fertilized eggs, fingerlings, and brood fish. Details for the tests with the different life stages, as well as the in-vitro bacterial tests, are provided below.

\subsection{In-Vitro Efficacy: Overnight Exposure}

Stock solutions of $F$. psychrophilum were prepared in sterile MAT broth (maltose and acetate supplemented tryptone-yeast-extract-salts media: $0.4 \%$ tryptone, $0.04 \%$ yeast extract, $0.05 \% \mathrm{CaCl}_{2}, 0.05 \% \mathrm{MgSO}_{4}, 1 \%$ maltose, and $0.02 \% \mathrm{C}_{2} \mathrm{H}_{3} \mathrm{NaO}_{2}$ [23]) using an isolate of a strain from southern Idaho (CSF 259-93 [24]). After $4 \mathrm{~d}$ incubation at $15^{\circ} \mathrm{C}$ on a stir-plate, $100 \mu \mathrm{L}$ was transferred to sterile culture tubes with $2 \mathrm{~mL}$ of non-inoculated, sterile MAT broth. The tube was agitated with a vortex mixer for 1 - $2 \mathrm{sec}$, then $1 \mathrm{~mL}$ of penicillin stock solution was added and the tube was mixed again. Four culture tubes were used for each penicillin stock concentration. Penicillin stock solutions were $0,1,10,100,1000,10,000$, 100,000 , and $1,000,000 \mathrm{IU} / \mathrm{mL}$, prepared by serial dilution with sterile well water $(222 \mathrm{mg} / \mathrm{L}$ total hardness as $\mathrm{CaCO}_{3}, 222 \mathrm{mg} / \mathrm{L}$ total alkalinity, $\mathrm{pH}$ 7.6). After mixing in the culture tubes, actual penicillin concentrations were $1 / 3$ of the stock solution concentrations. Therefore, the actual nominal penicillin concentrations that F. psychrophilum was exposed to were $0,0.33,3.33,33,330,3333$, 33,333 , and $333,333 \mathrm{IU} / \mathrm{mL}$. For this test and for subsequent trials, the concentrations are based on the IU/g tested and provided by the manufacturer for that particular lot of penicillin-G. Efforts were made during the test to control the temperature of the solutions, which varied from $15^{\circ} \mathrm{C}-20^{\circ} \mathrm{C}$. These temperatures are suitable for optimal growth of Flavobacterium psychrophilum [1]. The culture tubes were capped and held in an incubator at $15^{\circ} \mathrm{C}$ overnight. After $28 \mathrm{~h}$ incubation, $100 \mu \mathrm{L}$ of the culture solution was spread on a Petri plate with TYES agar (tryptone yeast extract salts; 0.4\% tryptone, 0.04\% yeast extract, $0.05 \% \mathrm{CaCl}_{2}, 0.05 \% \mathrm{MgSO}_{4}, 1.0 \%$ agar; [25]) using a sterile spreader and sterile barrier pipette tips. The dish was wrapped with laboratory film and incubated at $15^{\circ} \mathrm{C}$. Two media control plates (nothing spread on the plate) and two plates with sterile, non-inoculated MAT broth were also wrapped. All plates were evaluated for bacterial growth after $4 \mathrm{~d}$ incubation. Colony numbers and descriptions were noted for each plate.

Based on the results of the first trial, a subsequent test examined the concentrations between 100 and 1000 IU penicillin using the same protocol described above (4 replicates/dose). Stock concentrations of penicillin tested in this trial were $0,100,250,500,750$ and $1000 \mathrm{IU} / \mathrm{mL}$, prepared as serial dilutions with sterile well water. After mixing, actual concentrations were $1 / 3$ the stock concentration and therefore the actual concentrations tested were $0,33,83,167$, and $330 \mathrm{IU} / \mathrm{mL}$. For this trial, the penicillin solution was filter-sterilized by passing the stock solution through a $0.2 \mu \mathrm{m}$ syringe filter. The penicillin was fully dissolved before filtering.

\subsection{In-Vitro Efficacy: 15 Min Exposure}

Additional tests were conducted using a 15 min expo- 
sure to the penicillin solution. For these tests, a sterile plastic test strip $(50 \mathrm{~mm} \times 5 \mathrm{~mm}$ with a $5 \mathrm{~mm} \times 5 \mathrm{~mm}$ paper square affixed to the end of one side of the strip; EM Quant, EMD Chemicals, Gibbstown, New Jersey) was dipped into a solution of $F$. psychrophilum solution for $10 \mathrm{~s}$. The bacteria solution was made by transferring $1 \mathrm{~mL}$ of MAT broth (from a 3 day-old $F$. psychrophilum culture of strain CSF $259-93$ on a stir-plate at $15^{\circ} \mathrm{C}$ ) to 2 $\mathrm{mL}$ of sterile well water in a test tube and mixing. Using sterile forceps, the test strip was immediately transferred after the bacteria dip to a sterile test tube containing 4 $\mathrm{mL}$ of the penicillin solution. Penicillin concentrations of $0,10,100,1000,10,000,50,000,100,000,250,000$, and $500,000 \mathrm{IU} / \mathrm{mL}$ (actual nominal concentrations) were tested using 5 replicate tubes per concentration. These were prepared as serial dilutions using sterile well water. The starting stock penicillin solution was filter-sterilized. After $15 \mathrm{~min}$ in the penicillin solution, the strip was dipped in two tubes with sterile well water in succession, for $2 \mathrm{~s}$ in each. After this rinse, the strip tip was rubbed along the center axis of a Petri dish with TYES agar, rubbing one side in one direction and rubbing the other side of the strip to make another path going back across the plate. The plate was then wrapped with laboratory film and incubated at $15^{\circ} \mathrm{C}$. The plates were monitored for bacterial growth, noting colony numbers and type. Gram stains were made of yellow colony isolates to ensure they were consistent with F. psychrophilum.

\subsection{Effect of Penicillin-G on Eggs}

Penicillin concentrations of $0,250,500,1000,10,000$, 50,000, 100,000 IU/mL (actual concentration) were tested with rainbow trout eggs in $1 \mathrm{~h}$ exposures. Solutions were prepared by mixing powdered penicillin with Egan State Fish Hatchery (Utah Division of Wildlife Resources, Wayne County, Utah) well water $\left(9^{\circ} \mathrm{C}, 90\right.$ $\mathrm{mg} / \mathrm{L}$ total hardness, $90 \mathrm{mg} / \mathrm{L}$ total alkalinity) in $1 \mathrm{~L}$ plastic beakers. Since sterile water is not readily available at the hatchery, we used hatchery well water to model what the hatchery personnel would do if the process was initiated at the hatchery. Previous sampling of the well water had indicated it is not contaminated with $F$. psychrophilum. At 2 min after fertilization, rainbow trout eggs were rinsed with fresh hatchery well water and about $90 \mathrm{~mL}$ eggs were transferred to individual mesh bags made from mosquito netting. The bags were closed with a plastic zip-tie. There were three replicate bags for each concentration. The bags were transferred to the $1 \mathrm{~L}$ beakers containing penicillin. Separate penicillin solutions were prepared for each replicate. After $1 \mathrm{~h}$, the bags were transferred to a $100 \mathrm{mg} / \mathrm{L}$ iodine solution for 15 $\mathrm{min}$. The bags were rinsed in a bucket of fresh well water and transferred to coolers for transport to the Fisheries Experiment Station, Logan, Utah.
Upon arrival the eggs were treated one more time with $100 \mathrm{mg} / \mathrm{L}$ iodine for $10 \mathrm{~min}$. The iodine treatments were needed because penicillin is not a broad spectrum bactericide, fungicide, nor virucide [21]. The combination of treatments also modeled how penicillin treatments would be incorporated into the existing hatchery process for egg disinfection. The eggs were incubated in vertical stack incubator trays, with treatments assigned to different stacks to prevent contamination of eggs from lower concentration treatments (e.g., controls were located below the $250 \mathrm{IU} / \mathrm{mL}$ treatments, which were below the 500 $\mathrm{IU} / \mathrm{mL}$ eggs. Each stack of trays received $15 \mathrm{~L} / \mathrm{min}$ of well water at $13^{\circ} \mathrm{C}$. No further chemical treatments were given during incubation. At hatching (23 April 2010) and 3 days later, dead eggs were removed and counted. Crippled or deformed fry were also counted and removed. Live fry were also hand counted at the latter date to provide total egg counts. Percent hatch was expressed as a percentage of live fry over total initial eggs. The prevalence of deformities was expressed as a percentage of the fry that hatched.

\subsection{Effect of Penicillin-G on Fingerlings}

Rainbow trout fingerlings were given $200 \mu \mathrm{L}$ of penicillin by intraperitoneal (i.p.) injection with a 25 gauge needle. Eleven fish were injected for each treatment: 0,1 , 10, 100, 1000, 10,000, 100,000, and 500,000 IU/mL. Solutions were prepared by serial dilution of the highest concentration with sterile de-ionized water and using sterilized beakers. Each fish was weighed and measured for total length at the time of injection. Average length was $66 \pm 9.4 \mathrm{~mm}$ and average weight was $3.5 \pm 1.5 \mathrm{~g}$. The fish were put into $75 \mathrm{~L}$ glass aquaria that were part of a closed recycle system (see [26]) and monitored for $96 \mathrm{~h}$ for mortality. Fish were not fed during the first day of the study, but were fed 3 times per day on the following days. Water was exchanged daily (about $12 \%$ of total volume) in the recycle systems. Water temperature was $13.0^{\circ} \mathrm{C} \pm 0.2^{\circ} \mathrm{C}$.

Another round of testing was initiated the following week with another batch of fingerlings from the same lot (mean length and weight: $80 \pm 12.1 \mathrm{~mm}, 6.3 \pm 2.8 \mathrm{~g}$ ), evaluating penicillin concentrations of $0,10,000,20,000$, 40,000, 60,000, 80,000, 100,000, and 200,000 IU/mL. Sixteen fish per concentration treatment were given 200 $\mu \mathrm{L}$ (i.p.) and monitored for $96 \mathrm{~h}$.

\subsection{Effect of Penicillin-G on Adults}

Rainbow trout brood stock (average weight $=1210 \pm$ $678.4 \mathrm{~g}$; average length $=434 \pm 67.0 \mathrm{~mm} ; 2.5$ years old) were injected with penicillin at various concentrations to determine dosage limits for the antibiotic. There were 30 fish per treatment, each injected with $200 \mu \mathrm{L}$ of solution 
using a 21 gauge syringe. Treatments were 0 (control), $10,000,50,000,100,000,200,000,400,000$, and 800,000 $\mathrm{IU} / \mathrm{mL}$ of penicillin-G. Dilutions for the concentrations were done serially using de-ionized water. The 800,000 $\mathrm{IU} / \mathrm{mL}$ stock solution was filtered through a $0.22 \mu \mathrm{m}$ syringe filter to remove any bacteria. The penicillin was fully dissolved before attempting to filter the solution. Fish were anaesthetized with tricaine-methanesufonate (MS-222) prior to injection and measurement of total length and total body weight. Fish were given an intraperitoneal injection just posterior to the ventral fins, off the ventral midline. Each group of 30 fish was held in a separate outdoor, concrete, plug-flow raceway (water volume $2.41 \mathrm{~m}^{3}$ ). Fresh hatchery water at $16.4^{\circ} \mathrm{C} \pm 0.4^{\circ} \mathrm{C}$ flowed at an average rate of $20 \mathrm{~L} / \mathrm{min}$. Fish were fed a commercial pelleted feed ad-libidum during the study, beginning the second day after injection. Any mortalities were measured for total length and weight and the date noted during the $96 \mathrm{~h}$ trial.

\subsection{Statistical Analyses}

SPSS Version 13.0 was used for all analyses. Probit analysis was used to determine the $\mathrm{LD}_{10}$ and $\mathrm{LD}_{50}$ values for penicillin injected in fingerlings. Data were pooled from both trials for the analysis. ANOVA of arc-sine transformed data was used for comparing egg survival and deformity data. The colony forming unit (CFU) data were categorized into four categories of $\mathrm{CFU}$ abundance (0, 1 - 10, $11-100$, or $>100 \mathrm{CFU} /$ fish $)$ or were reduced to binomial data (present or absent) for analysis. Categorical data analysis compared CFU frequency distributions among penicillin concentrations and CFU categories in the egg toxicity experiment using the maximum likelihood statistic. For the fry resulting from the egg toxicity test, CFU data for spleen and kidney tissues were combined to provide a single result for each fish. Replicates effects were not significant $(P>0.05)$ for each concentration, so data were pooled across replicates for comparing CFU distributions among penicillin concentrations for each tissue. For adult rainbow trout mortality, the data were analyzed by a chi-square test and Somer's D statistic [27] was used to evaluate potential trends in mortality associated with penicillin concentration.

\section{RESULTS}

\subsection{In-Vitro Efficacy: Overnight Exposure}

Colonies typical of $F$. psychrophilum were observed in the positive control plates ( 0 IU penicillin) and at concentrations of $0.3,3.3$, and 33.3 IU (Table 1). No yellow colonies were observed in plates for the higher concentrations (333 to $3.33 \times 10^{5} \mathrm{IU} / \mathrm{mL}$ ). However, numerous

small, opaque, slow-growing, white colonies were observed. These were Gram-positive short rods. Gram staining of the yellow colony isolates indicated they were long Gram-negative rods typical of $F$. psychrophilum. Given that the test only used the known F. psychrophilum isolate and the powdered penicillin, and all other solutions and surfaces were sterile, we logically concluded that the white colonies were associated with the penicillin powder and the yellow colonies were a result of the isolate. If the yellow colonies came with the penicillin, then these should have grown on all the plates, which was not the case. No growth was observed on the media control plates or plates inoculated with MAT broth only.

Tests of the range between 33 and 333 IU penicillin indicated that no growth was observed after overnight exposure to 33 to 333 IU. Growth of yellow colonies was abundant in the positive control plates. A few slow growing white colonies were observed on one plate of the 33 IU treatment $(N=4)$, and two additional plates (83.3 IU, 333 IU) had minor fungal growth (1 - 5 colonies). Otherwise, no other bacterial colonies were observed on the plates up to $10 \mathrm{~d}$ after inoculation.

\subsection{In-Vitro Efficacy-15 Min Exposure}

In $15 \mathrm{~min}$ exposures to penicillin, yellow colonies of bacteria were not observed at concentrations of 10,000 $\mathrm{IU} / \mathrm{mL}$ or higher (Figure 1). Exposure to 10 or 100 $\mathrm{IU} / \mathrm{mL}$ reduced bacterial abundance relative to unexposed controls, but not significantly. At $1000 \mathrm{IU} / \mathrm{mL}$, the prevalence of yellow CFUs was significantly lower than controls $\left(P=0.02\right.$, d.f. $\left.=1, \chi^{2}=4.29\right)$, but 2 of 5 plates still had 1 yellow CFU that survived the penicillin treatment.

Table 1. Percentage of plates ( $N=4$ per concentration) with $\geq 1$ yellow colony forming unit(s) for Flavobacterium psychrophilum solutions exposed to various concentrations of penicillin-G for $28 \mathrm{~h}$ and plated on TYES media.

Penicillin Concentration (IU/mL)

0

0.3

3.3

$3.33 \times 10^{1}$

$3.33 \times 10^{2}$

$3.33 \times 10^{3}$

$3.33 \times 10^{4}$

$3.33 \times 10^{5}$
Percentage of Plates with Yellow CFUs

100

100

100

75

0

0

0

0 


\subsection{Effect of Penicillin-G on Eggs}

The percent hatch did not significantly differ among penicillin treatments $(P=0.91$, d.f. $=20, \mathrm{~F}=0.32$; Table 2). Mean percent hatch values ranged from $64.6 \%$ (control) to $75.1 \%(1000 \mathrm{IU} / \mathrm{mL}$ treatment) among the treatments. The percentage of deformed fry ranged from $0.3 \%(100,000 \mathrm{IU} / \mathrm{mL})$ to $6.8 \%(1000 \mathrm{IU} / \mathrm{mL})$, and $\mathrm{did}$ not significantly differ among treatments $(P=0.17$, d.f. $=$ $20, \mathrm{~F}=1.82$ ).

\subsection{Effect of Penicillin-G on Fingerlings}

No mortality was observed for fry injected with penicillin concentrations of $\leq 10,000 \mathrm{IU} / \mathrm{mL}$. However, concentrations of $100,000 \mathrm{IU} / \mathrm{mL}$ or greater resulted in significant mortality $\left(\geq 73 \% ; P<0.01\right.$, d.f. $=1, \chi^{2} \geq 12.6$; Figure 2(a)). All of the mortality occurred within the first $24 \mathrm{~h}$. In the $100,000 \mathrm{IU} / \mathrm{mL}$ treatment, the fish that died were a wide range of sizes (56 to $81 \mathrm{~mm}$ ).

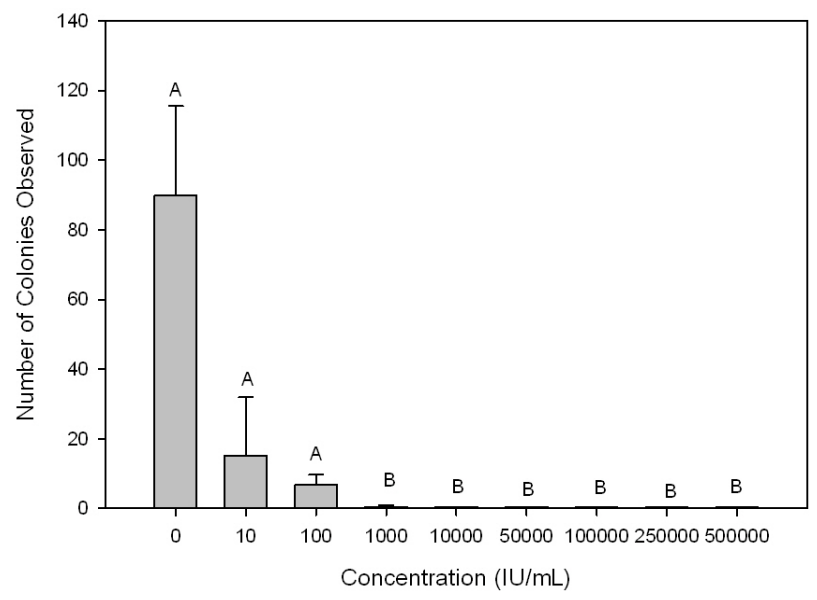

Figure 1. Number of yellow bacterial colonies observed on TYES media after wiping the surface with a plastic strip that had been dipped in a solution of Flavobacterium psychrophilum, then dipped in a penicillin solution of various concentrations for $15 \mathrm{~min}$ and rinsed twice. A common letter over the bars indicates that the means are not significantly different from each other $(P<0.05)$.

Table 2. Mean survival to hatch and percentage of deformed fry $( \pm \mathrm{SD})$ for eggs treated for $1 \mathrm{~h}$ during water hardening with various concentrations of penicillin-G.

\begin{tabular}{lll}
\hline $\begin{array}{l}\text { Penicillin Concentration } \\
(\mathrm{IU} / \mathrm{mL})\end{array}$ & $\begin{array}{l}\text { Survival to Hatch } \\
(\%)\end{array}$ & $\begin{array}{l}\text { Deformed } \\
(\%)\end{array}$ \\
\hline 0 & $64.6 \pm 23.4$ & $2.1 \pm 1.3$ \\
250 & $72.0 \pm 2.7$ & $0.8 \pm 0.9$ \\
500 & $70.1 \pm 3.0$ & $1.4 \pm 1.2$ \\
1000 & $75.1 \pm 6.8$ & $6.8 \pm 0.3$ \\
10,000 & $66.8 \pm 7.8$ & $0.7 \pm 0.8$ \\
50,000 & $67.4 \pm 6.0$ & $0.6 \pm 0.4$ \\
100,000 & $66.5 \pm 0.3$ & $0.3 \pm 0.3$ \\
\hline
\end{tabular}

In the second test, there were significant differences among penicillin concentrations in the cumulative mortality $\left(P<0.01\right.$, d.f. $\left.=4, \chi^{2}=49.8\right)$. No mortality was observed in controls or fish receiving 10,000 or 20,000 $\mathrm{IU} / \mathrm{mL}$ penicillin. However, low levels of mortality were observed in the $40,000 \mathrm{IU} / \mathrm{mL}$ treatment $(6.2 \%)$, with increasing mortality observed as penicillin concentrations increased (Figure 2(b)). The mortality was significantly higher in the 80,000 and $100,000 \mathrm{IU} / \mathrm{mL}$ treatments than in controls $\left(P<0.01\right.$, d.f. $\left.=1, \chi^{2} \geq 9.0\right)$, but lower concentrations did not significantly differ from controls $(P>0.23)$. Probit analysis resulted in a $\mathrm{LD}_{10}$ of 52,868 IU/mL (95\% confidence limits: 31,522 - 69,490 $\mathrm{IU} / \mathrm{mL})$ and $\mathrm{LD}_{50}$ of $131,466 \mathrm{IU} / \mathrm{mL}(113,095-157,878$ $\mathrm{IU} / \mathrm{mL})$.

\subsection{Effect of Penicillin-G on Adults}

Cumulative mortality over $96 \mathrm{~h}$ ranged from 0.0 to

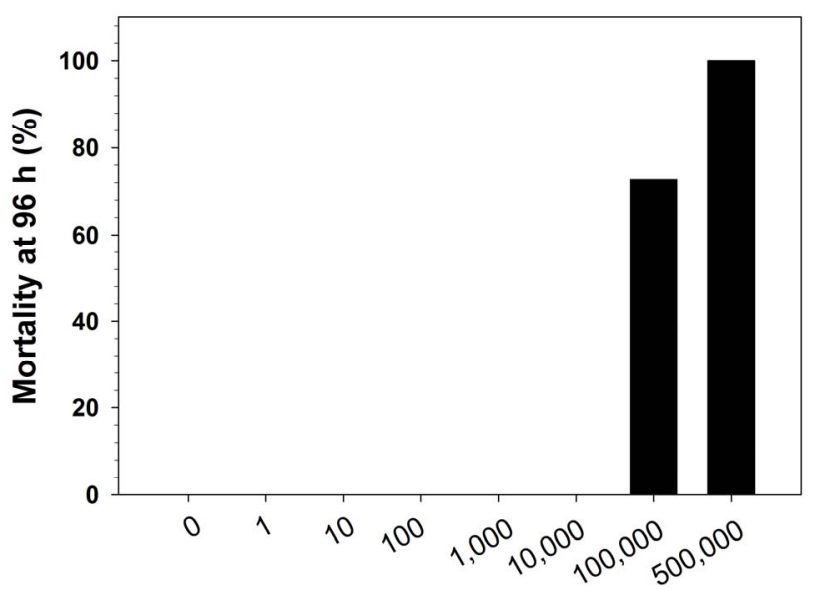

(a)

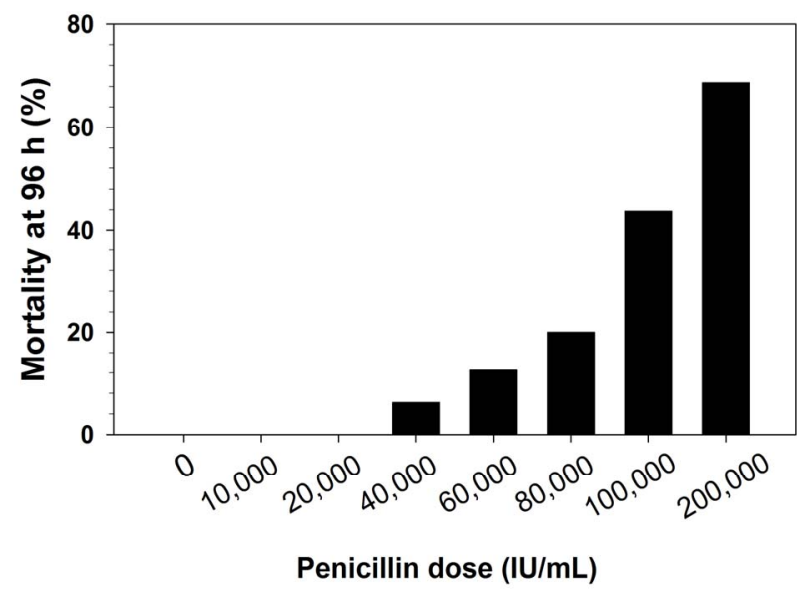

(b)

Figure 2. Cumulative percent mortality after $96 \mathrm{~h}$ for rainbow trout fingerlings after intraperitoneal injection of various doses of penicillin-G. Graph A shows test 1 results $(N=11$ per dose $)$, graph B test 2 results $(N=16$ per dose). 
$7.1 \%(50,000 \mathrm{IU} / \mathrm{mL})$ and did not significantly differ among treatments $\left(P=0.37\right.$, d.f. $=6, \chi^{2}=5.2$; Table 3$)$. The Somers D (symmetric statistic $=0.012)$ indicated no significant ordinal trends $(P=0.60)$.

\section{DISCUSSION}

Fish eggs can serve as vectors for the transfer of pathogens. So disease control strategies include treating the eggs directly or treating them indirectly within the infected brood stock prior to spawning. For treatment of fish eggs directly, several authors have reported success reducing or eliminating bacterial pathogens using antibiotics. For example, Oppenheimer [28] significantly improved hatching success using penicillin $G$ and streptomycin $(50 \mathrm{mg} / \mathrm{L}$ of each) to treat eggs of Sardinops, Pleuronichthys and Gadus; Aureomycin and polymyxin combined also gave good results. Similarly Peck et al. [29] found that $24 \mathrm{~h}$ treatment of Atlantic cod Gadus morhua or haddock Melanogrammus aeglefinus eggs with a $0.005 \%$ solution of penicillin-streptomycin improved hatching success. Arenzon et al. [30] used a mixture of penicillin (1185 IU/L) and mycostatin (562 IU/L) to successfully incubate eggs of Cynopoecilus melanotaenia in-vitro. Jensen et al. [31] used $2 \mathrm{mg} / \mathrm{L}$ erythromycin for $1 \mathrm{~h}$ during water hardening of coho salmon Oncorhynchus kisutch and steelhead O. mykiss eggs to successfully eliminate Renibacterium salmoninarum from the eggs. In contrast, a shorter exposure $(30 \mathrm{~min})$ to the same concentration of erythromycin, or to proflavin $(200 \mathrm{mg} / \mathrm{L}$ for $0.5-1 \mathrm{~h})$, or penicillin-G $(50 \mathrm{IU} / \mathrm{mL}$ for 1 h) did not completely eliminate $R$. salmoninarum from Atlantic salmon Salmo salar eggs [32]. Higher concentrations of erythromycin $(50 \mathrm{mg} / \mathrm{L})$ for $2 \mathrm{~h}$ were effective against $R$. salmoninarum in steelhead, coho salmon, and Chinook salmon Oncorhynchus tshawytscha eggs [33].

Barnes et al. [34] used streptomycin or tetracycline on rainbow trout eggs infected with $F$. columnare, improving hatching success and reducing bacterial abundance. However to our knowledge, no tests have evaluated antibiotic use on eggs for control of F. psychrophilum or evaluated potential limits for penicillin concentrations.

Table 3. Percent mortality ( 96 h cumulative, $N=28$ to $30 /$ dose) in 2.5 year old rainbow trout injected intraperitoneally with 200 $\mu \mathrm{L}$ of various concentrations of penicillin-G.

\begin{tabular}{cc}
\hline Penicillin Concentration $(\mathrm{IU} / \mathrm{mL})$ & Mortality $(\%)$ \\
\hline 0 & 3.3 \\
10,000 & 0.0 \\
50,000 & 7.1 \\
100,000 & 0.0 \\
200,000 & 3.3 \\
400,000 & 3.3 \\
800,000 & 0.0 \\
\hline
\end{tabular}

The data in this study indicated that rainbow trout eggs were tolerant of up to at least $100,000 \mathrm{IU} / \mathrm{mL}$ of penicillin. Subsequent rearing of the fish from these egg treatments indicated normal hatchery performance. In-vitro testing indicated that $F$. psychrophilum was susceptible to penicillin concentrations of $\geq 10,000 \mathrm{IU} / \mathrm{mL}$ if exposed for $15 \mathrm{~min}$ or $333 \mathrm{IU}$ if exposed overnight. The high tolerance of eggs to penicillin treatment indicates higher concentrations of penicillin could be safely used for egg treatment to control transfer of $F$. psychrophilum and other susceptible pathogens from brood sources to rearing hatcheries. Based on the experiences of Gee and Sarles [35], who noted differences between in-vitro tests and in-vivo tests with salmonid eggs in chemical concentrations required to kill bacteria causing furunculosis, higher concentrations may be needed in-vivo than observed in the in-vitro tests of this study.

Injections of penicillin appear to be toxic to fingerling rainbow trout if the concentration exceeds $20,000 \mathrm{IU} / \mathrm{mL}$ (4000 IU/fish). However, injections of larger brood fish with similar concentrations did not appear to cause any harm. So size does appear to have an influence on toxicity, with larger fish tolerating higher concentrations. Even the slight difference in size between weeks in the fingerling toxicity tests indicated that the larger fish had slightly lower mortality. The mechanism of the toxicity is unknown. However, studies in mammals have indicated that anaphylaxis, immune-mediated hemolytic anemia, electrolyte imbalances, neutropenia, or leucopenia may result from penicillin use [21,36-38].

Injection of brood stock with antibiotics is another strategy for controlling vertical transmission of bacterial pathogens [39,40]. Evelyn et al. [33] observed that injection of brood stock 30 - $56 \mathrm{~d}$ before spawning with 20 $\mathrm{mg}$ erythromycin per $\mathrm{kg}$ fish led to eggs that were not infected with $R$. salmoninarum. The antibiotic was found in the yolk, contrasting with eggs bathed in antibiotic during water hardening, which had antibiotic only in the perivitelline fluid. Working with coho salmon, Brown et al. [41] evaluated five antibiotics, including penicillin $\mathrm{G}$ $(50 \mathrm{mg} / \mathrm{kg}$ fish), and concluded that all were effective in reducing the proportion of alevins infected with $R$. salmoninarum. Further testing is needed to determine if this dose is still effective in a variety of salmonid species. Bacterial resistance to antibiotics is an on-going phenomenon [42,43], and resistance among Flavobacterium has been noted [10]. Bustos et al. [17] noted that a Chilean isolate of F. psychrophilum was not susceptible to penicillin, phosphomycin, and sulfa-trimethoprim, but doses of the sensitivity disks were not reported. The data from this study indicated that penicillin concentrations of up to $800,000 \mathrm{IU} / \mathrm{mL}$ (160,000 IU/fish) were tolerated by brood fish. DeCew [39] also observed that adult Chinook salmon tolerated penicillin-G doses of 13,000 to 87,000 
$\mathrm{IU} / \mathrm{kg}$. So, high penicillin concentrations could potentially be used to combat systemic infections with F. psychrophilum and control vertical transmission of the pathogen. Currently however, penicillin-G is not approved for use in fish in the US While the antibiotic is widely used in human and veterinary medicine, further research is needed in a variety of fish families to determine appropriate penicillin doses for effective control of a variety of bacterial pathogens. Penicillin quickly breaks down in aqueous solutions or after injection, leading to short regulatory withdrawal times for mammals [21,44]. For fish, additional research is needed to determine appropriate withdrawal times at different temperatures and antibiotic doses. Any attempt to supply the antibiotic orally would also require more research into appropriate doses, treatment duration, frequency of reapplication, feed palatability issues, conflicts with other gut flora, and of course, efficacy.

In summary, the data indicated that penicillin can be safely used for egg disinfection or injected into brood stock for control of F. psychrophilum in rainbow trout, using concentrations that are up to ten times the concentration required to kill the bacterium in-vitro. The susceptibility of F. psychrophilum to penicillin in in-vitro tests suggests that penicillin could potentially control the pathogen and its transport from brood sources to rearing hatcheries. Further testing is recommended to determine appropriate concentrations and timing for brood stock injections. Similarly, further research is needed to determine appropriate concentrations and durations for treating eggs with penicillin either by itself or combined with other antibiotics.

\section{ACKNOWLEDGEMENTS}

We thank the staff at the J. Perry Egan State Fish Hatchery for their help with the study and the eggs used for the tests. We thank M.D. Routledge and his staff at the Fisheries Experiment Station for rearing and caring for the fish used in this study. The research was supported by the Utah Division of Wildlife Resources and the Federal Aid in Sport Fish Restoration program, Grant F74-R.

\section{REFERENCES}

[1] Cipriano, R.C. and Holt, R.A. (2005) Flavobacterium psychrophilum, cause of bacterial cold-water disease and rainbow trout fry syndrome. Fish Disease Leaflet 86, US Geological Survey, National Fish Health Laboratory, Kearneysville, West Virginia.

[2] Wagner, E.J., Oplinger, R.W., Arndt, R.E., Forest, A.M. and Bartley, M. (2010) The safety and effectiveness of various hydrogen peroxide and iodine treatment regimens for rainbow trout egg disinfection. North American Journal of Aquaculture, 72, 34-42. doi:10.1577/A09-005.1

[3] Kumagai, A., Takahashi, K., Yamaoka, S. and Waka- bayashi, H. (1998) Ineffectiveness of iodophore treatment in disinfecting salmonids eggs carrying Cytophaga psychrophila. Fish Pathology, 33, 123-128. doi:10.3147/jsfp. 33.123

[4] Cipriano, R.C. (2005) Intraovum infection caused by Flavobacterium psychrophilum among eggs from captive Atlantic salmon broodfish. Journal of Aquatic Animal Health, 17, 275-283. doi:10.1577/H05-003.1

[5] Wagner, E.J., Arndt, R.E., Billman, E.J., Forest, A. and Cavender, W. (2008) Comparison of the efficacy of iodine, formalin, salt, and hydrogen peroxide for control of external bacteria on rainbow trout eggs. North American Journal of Aquaculture, 70, 118-127. doi:10.1577/A06-068.1

[6] Brown, L.L., Cox, W.T. and Levine, R.P. (1997) Evidence that the causal agent of bacterial cold-water disease Flavobacterium psychrophilum is transmitted within salmonids eggs. Diseases of Aquatic Organisms, 29, 213218. doi:10.3354/dao029213

[7] Evelyn, T.P.T., Ketcheson, J.E. and Prosperi-Porta, L. (1984) Further evidence for the presence of Renibacterium salmoninarum in salmonid eggs and the failure of povidone-iodine to reduce the intra-ovum infection rate in water-hardened eggs. Journal of Fish Diseases, 7, 173182. doi:10.1111/j.1365-2761.1984.tb00921.x

[8] Rangdale, R.E., Richards, R.H.J. and Alderman, D.J. (1997) Minimum inhibitory concentrations of selected antimicrobial compounds against Flavobacterium psychrophilum the causal agent of rainbow trout fry syndrome (RTFS). Aquaculture, 158, 193-201. doi:10.1016/S0044-8486(97)00202-0

[9] Dalsgaard, I., and Madsen, L. (2000) Bacterial pathogens in rainbow trout, Oncorhynchus mykiss (Walbuam), reared at Danish freshwater farms. Journal of Fish Diseases, 23, 199-209. doi:10.1046/j.1365-2761.2000.00242.x

[10] Bruun, M.S., Schmidt, A.S., Madsen, L. and Dalsgaard, I. (2000) Antimicrobial resistance patterns in Danish isolates of Flavobacterium psychrophilum. Aquaculture, 187, 201-212. doi:10.1016/S0044-8486(00)00310-0

[11] Schmidt, A.S., Bruun, M.S., Dalsgaard, I., Pedersen, K. and Larsen, J.L. (2000) Occurrence of antimicrobial resistance in fish-pathogenic and environmental bacteria associated with four Danish rainbow trout farms. Applied and Environmental Microbiology, 66, 4908-4915. doi:10.1128/AEM.66.11.4908-4915.2000

[12] Kum, C., Kirkan, S., Sekkin, S., Akar, F. and Boyacioglu, M. (2008) Comparison of in-vitro antimicrobial susceptibility in Flavobacterium psychrophilum isolated from rainbow trout fry. Journal of Aquatic Animal Health, 20, 45-251. doi:10.1577/H07-040.1

[13] Hesami, S., Parkman, J., MacInnes, J.I., Gray, J.T., Gyles, C.L. and Lumsden, J.S. (2010) Antimicrobial susceptibility of Flavobacterium psychrophilum isolates from Ontario. Journal of Aquatic Animal Health, 22, 39-49. doi:10.1577/H09-008.1

[14] Watts, J.L., et al. (2010) Performance standards for antimicrobial disk and dilution susceptibility tests for bacteria isolated from animals; approved standard-3rd edition. 
Clinical and Laboratory Standards Institute, M31-A3, 28. www.clsi.org/source/orders/free/m31-a3.pdf

[15] Bruun, M.S., Madsen, L. and Dalsgaard, I. (2003) Efficiency of oxytetracycline treatment in rainbow trout experimentally infected with Flavobacterium psychrophilum strains having different in vitro antibiotic susceptibilities. Aquaculture, 215, 11-20. doi:10.1016/S0044-8486(01)00897-3

[16] Soltani, M., Shankar, S. and Munday, B.L. (1995) Chemotherapy of Cytophaga/Flexibacter-like bacteria (CFLB) infections in fish: Studies validating clinical efficacies of selected antimicrobials. Journal of Fish Diseases, 18, 555-565. doi:10.1111/j.1365-2761.1995.tb00360.x

[17] Bustos, P.A., Calbuyahue, J., Montaña, J., Poazo, B., Entrala, P. and Solervicens, R. (1995) First isolation of Flexibacter psychrophilus, as causative agent of rainbow trout fry syndrome (RTFS), producing rainbow trout mortality in Chile. Bulletin of the European Association of Fish Pathologists, 15, 162-164.

[18] Weinstein, L. (1965) Antibiotics. II. Penicillin. In: Goodman, L.S. and Gilman, A., Eds., The Pharmacological Basis of Therapeutics, 3rd Edition, MacMillan Co., New York, 1193-1229.

[19] Donowicz, G.R. and Mandell, G.L. (1988). Beta-lactam antibiotics. New England Journal of Medicine, 318, 419426. doi:10.1056/NEJM198802183180706

[20] Austin, B. (1985) Evaluation of antimicrobial compounds for the control of bacterial kidney disease in rainbow trout, Salmo gairdneri Richardson. Journal of Fish Diseases, 8, 209-220. doi:10.1111/j.1365-2761.1985.tb01216.x

[21] US Pharmacopeial Convention (2007) Penicillin G. http://vetmed.tamu.edu/common/docs/public/aavpt/penici llinG.pdf

[22] Lumsden, J.S., Ostland, V.E. and Ferguson, H.W. (1996) Necrotic myositis in cage cultured rainbow trout, Oncorhynchus mykiss (Walbaum), caused by Flexibacter psychrophilus. Journal of Fish Diseases, 19, 113-119. doi:10.1111/j.1365-2761.1996.tb00689.x

[23] Crump, E.M., Perry, M.B., Clouthier, S.C. and Kay, W.W. (2001) Antigenic characterization of the fish pathogen Flavobacterium psychrophilum. Applied and Environmental Microbiology, 67, 750-759. doi:10.1128/AEM.67.2.750-759.2001

[24] MacLean, L.L., Vinogradov, E., Crump, E.M., Perry, M.B. and Kay, W.W. (2001) The structure of the lipopolysaccharide O-antigen produced by Flavobacterium psychrophilum (259-93). European Journal of Biochemistry, 268, 2710-2716. doi:10.1046/j.1432-1327.2001.02163.x

[25] Cepeda, C., Garcia-Marquez, S. and Santos, Y. (2004) Improved growth of Flavobacterium psychrophilum using a new culture medium. Aquaculture, 238, 75-82. doi:10.1016/j.aquaculture.2004.05.013

[26] Wagner, E.J., Wilson, C., Arndt, R., Goddard, P., Miller, M., Hodgson, A., Vincent, R. and Mock, K. (2006) Evaluation of disease resistance of the Fish Lake-DeSmet, Wounded Man, and Harrison Lake strains of rainbow trout exposed to Myxobolus cerebralis. Journal of Aquatic Animal Health, 18, 128-135.
doi:10.1577/H05-039.1

[27] Agresti, A. (1990) Categorical data analysis. Wiley and Sons, New York.

[28] Oppenheimer, C.H. (1955) The effect of marine bacteria on the development and hatching of pelagic fish eggs, and the control of such bacteria by antibiotics. Copeia, 1955, 43-49. doi:10.2307/1439451

[29] Peck, M.A., Buckley, L.J., O’Bryan, L.M., Davies, E.J. and Lapolla, A.E. (2004) Efficacy of egg surface disinfectants in captive spawning Atlantic cod Gadus morhua L. and haddock Melanogrammus aeglefinus L. Aquaculture Research, 35, 992-996.

doi:10.1111/j.1365-2109.2004.01119.x

[30] Arenzon, A., Lemos, C.A. and Bohrer, M.B.C. (2002) The influence of temperature on the embryonic development of the annual fish Cynopoecilus melanotaenia (Cyprinodontiformes, Rivulidae). Brazilian Journal of Biology, 62, 743-747. doi:10.1590/S1519-69842002000500002

[31] Jensen, J.P.T., McLean, W.E., and Alderdice, D.F. (1981) Effects of accessory factors on survival of newly fertilized salmonid eggs treated with an antibiotic. Aquaculture, 23, 295-307. doi:10.1016/0044-8486(81)90023-5

[32] Bruno, D.W. and Munro, A.L.S. (1986) Observations on Renibacterium salmoninarum and the salmonid egg. Diseases of Aquatic Organisms, 1, 83-87. doi:10.3354/dao001083

[33] Evelyn, T.P.T., Ketcheson, J.E. and Prosperi-Porta, L. (1986) Use of erythromycin as a means of preventing vertical transmission of Renibacterium salmoninarum. Diseases of Aquatic Organisms, 2, 7-11. doi:10.3354/dao002007

[34] Barnes, M.E., Bergmann, D. Jacobs, J. and Gabel, M. (2009) Effect of Flavobacterium columnare inoculation, antibiotic treatments and resident bacteria on rainbow trout Oncorhynchus mykiss eyed egg survival and external membrane structure. Journal of Fish Biology, 74, 576-590. doi:10.1111/j.1095-8649.2008.02147.x

[35] Gee, L.L., and Sarles, W.B. (1942) The disinfection of trout eggs contaminated with Bacterium salmonicida. Journal of Bacteriology, 44, 111-126.

[36] Embrechts, E. (1982) Procaine penicillin toxicity in pigs. Veterinary Record, 111, 314. doi:10.1136/vr.111.14.314

[37] Blue, J.T., Dinsmore, R.P. and Anderson, K.L. (1987) Immune-mediated hemolytic anemia induced by penicillin in horses. Cornell Veterinarian, 77, 263-276.

[38] Nielsen, I.L., Jacobs, K.A., Huntington, P.J., Chapman, C.B. and Lloyd, K.C. (1988) Adverse reaction to procaine penicillin $\mathrm{G}$ in horses. Australian Veterinary Journal, 65, 181-185. doi:10.1111/j.1751-0813.1988.tb14296.x

[39] DeCew, M.G. (1972) Antibiotic toxicity, efficacy, and teratogenicity in adult spring Chinook salmon (Oncorhynchus tshawytscha). Journal of the Fisheries Research Board of Canada, 29, 1513-1517. doi: 10.1139/f72-239

[40] Bullock, G.L. and Leek, S.L. (1986) Use of erythromycin in reducing vertical transmission of bacterial kidney disease. Veterinary and Human Toxicology, 28, 18-20. 
[41] Brown, L.L., Albright, L.J. and Evelyn, T.P.T. (1990) Control of vertical transmission of Renibacterium salmoninarum by injection of antibiotics into maturing female coho salmon Oncorhynchus kisutch. Diseases of Aquatic Organisms, 9, 127-131. doi:10.3354/dao009127

[42] Walter, W.M. and Vennes, J.W. (1985) Occurrence of multiple antibiotic resistance enteric bacteria in domestic sewage and oxidation ponds in Lagos. Applied and Environmental Microbiology, 50, 930-933.
[43] Ogbondeminu, F.S. and Olayemi, A.B. (1993) Antibiotic resistance in enteric bacterial isolates from fish and water media. Journal of Aquaculture in the Tropics, 8, 207-212.

[44] Payne, M.A., Craigmill, A., Riviere, J.E. and Webb, A.I. (2006) Extralabel use of penicillin in food animals. Journal of the American Veterinary Medical Association, 229, 1401-1403. doi:10.2460/javma.229.9.1401 